Masculine Compromise: Migration, Family, and Gender in China, by Susanne Y. P. Choi and Yinni Peng. Oakland: University of California Press, 2016. $x+179$ pp. US\$85.00/£70.95 (cloth), US\$29.95/£24.95 (paper), US $\$ 29.95$ (eBook).

Most previous books about migrant workers from rural China have focused on female factory workers and domestics. This book helps fill a major gap by focusing on the tens of millions of male migrants. The findings derive predominantly from interviews with 192 male and 74 women respondents, carried out by the two authors plus 12 other interviewers in the industrialized Pearl River Delta region of Guangdong.

The book takes full account of the fact that migrant workers are no longer predominantly in their late teens to early twenties. A great many are in their thirties, forties, and older, and, as a result, many of the men are married and have children. Most of the chapters in Masculine Compromise deal with the dilemmas men face as husbands and fathers away from their home villages.

The first and second chapters discuss the institutional context in which China's system of work migration operates. These chapters necessarily are based largely on documentation, but chapter 2 enlivens a reader's interest by weaving into this discussion the stories of four typical men. Chapter 3 examines young, unmarried male migrants and their efforts to find a partner. Though migration to the city offers them opportunities to romantically engage with young women migrants, the chapter shows that a considerable number of them bend to the wishes of their parents to marry a young woman from their home district, sometimes through an arranged engagement.

The remaining five chapters deal with migrant men who are married. Chapter 4 examines the negotiated decisions between the partners over postmarital living arrangements: whether the wife should join her husband in the city, who controls what types of spending, and the extent to which the husband can act in a patriarchal fashion in the city.

Chapter 5 examines an important aspect of this arrangement. The migrant wife normally works very long hours at a factory job, which makes it difficult for her to also take care of all of the cooking and housekeeping. The customary rural division of labor, in which women tend to almost all of the household work, has changed in this new setting. But the degree to which a husband is willing to share in house chores, and the types of chores that he considers appropriate for a man, vary among couples, and the authors explore these patterns and what they tell us about notions of masculinity.

Chapter 6 suggests that most of the married male workers need to leave their children behind in the village with the grandparents or wife. Many of the respondents feel a sense of "guilt toward their left-behind children. Although most migrant men worked very hard to provide for their families, especially their left- 
behind children, the emotional costs of their migration were so huge that the majority of them believed that the material benefits could not cure the pain suffered by both parties, and few defined themselves as 'good fathers'” (123).

Chapter 7 focuses on the migrant men's traditional obligations to provide financial and physical care for their elderly parents. They believe they should, but most of them neglect to do so adequately: "Although most migrant men give their parents some financial help, this is often symbolic rather than substantive" (138). In fact, "in most cases parents give far more support to their migrant children than vice versa" (132). While the men express respect for their parents and sometimes have feelings of guilt, they have transferred their filial obligation to a strong sense of responsibility for their children's future, often with their parents' concurrence. To a surprising degree, the men sacrifice to provide for their children's education. As a typical respondent noted, "when our children are born, the only thing that matters is how we can earn money to support them, and pay for their education... There are no other options" (80). Many men work as much as 13-15 hours a day to augment their income, sometimes taking on more than one job.

The book does not mention the social science literature about morality in contemporary China and the implicit debate within this literature over whether there has been a breakdown in moral standards in China or a rejuvenation. (Yunxiang Yan, Xin Liu, John Osburg, Ellen Oxfeld, and Charles Stafford, among others, have staked out informed stances on this.) Masculine Compromise inadvertently contributes to this literature. This large cohort of men from the countryside normally act in a highly ethical, altruistic fashion by sacrificing a great deal to uphold their moral obligations to their children and their children's future.

The book's one drawback is that the authors do not take full advantage of the sample of 192 male migrants. The book does contain some statistics (e.g., 44 percent of the surveyed migrant men whose wives are with them participate in housework [150], and almost 80 percent of the male respondents defined manhood predominantly in terms of being a provider [79]). But there are far too few instances of such hard facts and practically no correlations, and thus the book is often unnecessarily vague about how prevalent various attitudes and social practices are among the respondents. Overall, though, Masculine Compromise is a valuable contribution to our understanding of the vast cohort of male Chinese migrants as they attempt to navigate changing identities as husbands and fathers.

\section{Jonathan Unger}

Australian National University 